\title{
Secular Trend and Geographical Variation in Hepatitis A Infection and Hepatitis B Carrier Rate Among Adolescents in Taiwan: An Island-Wide Survey
}

\author{
Liang-Yueh Wang, Ya-Wen Cheng, Shan-Ju Chou, Ling-Ling Hsieh, and Chien-Jen Chen \\ Institute of Biomedical Sciences, Academia Sinica (L.-Y.W., Y.-W.C., C.-J.C.), Institute of Public Health, National \\ Taiwan University College of Medicine (S.-J.C., C.-J.C.), and Department of Public Health, Chang-Gung Medical \\ College (L.-L.H.), Taipei, Taiwan, Republic of China
}

During the last two decades an economic boom has occurred in Taiwan, a region where the prevalence of both hepatitis $A$ and $B$ virus infection was formerly very high. To examine the impact of socioeconomic developments on the secular trend and geographical variation in hepatitis $A$ and $B$ virus infection, 875 adolescents selected randomly from 20 junior high schools were studied. Serum samples collected from the subjects were tested for hepatitis A antibody (anti-HAV) and hepatitis $B$ surface antigen (HBsAg) by enzyme immunoassay using commercial reagents. The anti-HAV prevalence increased from northern through central to southern Taiwan; the prevalence was highest in aboriginal townships and lowest in metropolitan precincts. This striking variation in anti-HAV prevalence in different geographical locations and at different urbanization levels remained significant in multiple logistic regression analysis. The $\mathrm{HBsAg}$ prevalence was significantly higher in aboriginal townships than in rural and urban townships and metropolitan precincts. In addition, HBsAg prevalence was related inversely to the number of physicians per 1,000 population. The prevalence of both anti-HAV and HBsAg declined significantly during the last decade in Taipei City and County. The decrease in anti-HAV prevalence may be due to improvements in environmental hygiene, water supply, and food sanitation, while the decline in the HBsAg carrier rate may result from the use of disposable needles and syringes as well as screening for HBsAg in blood banks.

(c) 1993 Wiley-Liss, Inc.

\section{INTRODUCTION}

Taiwan is a hyperendemic area for hepatitis $A$ and $B$ viruses. Until 1980, the seroprevalence of hepatitis A virus (HAV) infection was higher than $90 \%$, with most HAV infection occurring during childhood [Wu et al., 1980a; Hwang et al., 1983; Sung et al., 1980]. A striking decline in the prevalence of HAV infection was observed among children in Taipei City in 1984 [Hsu et al., 1985]. However, the secular trend of HAV prevalence outside the capital city has never been examined. Significant geographical variation in HAV infection prevalence in different areas of Taiwan has been reported, and the HAV prevalence among children was related inversely to maternal educational level [Chen et al., 1990]. Due to Taiwan's economic boom during recent years, there have been obvious improvements in environmental hygiene, sewage disposal and water supply [Department of Health, 1990]. Therefore, it is postulated that $\mathrm{HAV}$ infection prevalence in Taiwan might decline further in both rural and urban areas during the 1990s.

Hepatitis B virus (HBV) is highly prevalent in Taiwan; the $\mathrm{HBV}$ infection rate is as high as $90 \%$ and the $\mathrm{HBV}$ surface antigen ( $\mathrm{HBsAg}$ ) carrier rate is $15-20 \%$ among adults in the general population [Beasley, 1975; Wu et al., 1980bl. To intervene in the transmission of HBV among the general population and to prevent the subsequent occurrence of chronic liver disease including cirrhosis and hepatocellular carcinoma, a stepwise mass vaccination program has been implemented in Taiwan since 1984 [Hsu, 1990]. Only neonates born to $\mathrm{HBsAg}$ carrier mothers were vaccinated from July 1984 to June 1986 , but all neonates have been immunized since July 1986. However, the reasons for hyperendemicity of $\mathrm{HBV}$ in Taiwan before the vaccination campaign remain to be elucidated. Children of HBsAgcarrier parents and those who live in aboriginal areas have a higher HBV infection rate [Chen et al., 1990]. In addition, horizontal transmission has been reported as an important determinant of $\mathrm{HBsAg}$ carriage among children in Taiwan [Beasley, 1975; Stevens et al., 1975; Chung et al., 1989], but the secular trend and geographical variation in the $\mathrm{HBsAg}$ carrier rate in Taiwan have never been examined.

Accepted for publication June 15, 1992.

Address reprint requests to Prof. Chien-Jen Chen, Institute of Biomedical Sciences, Academia Sinica, Nan-Kang, Taipei 11529, Taiwan, Republic of China. 


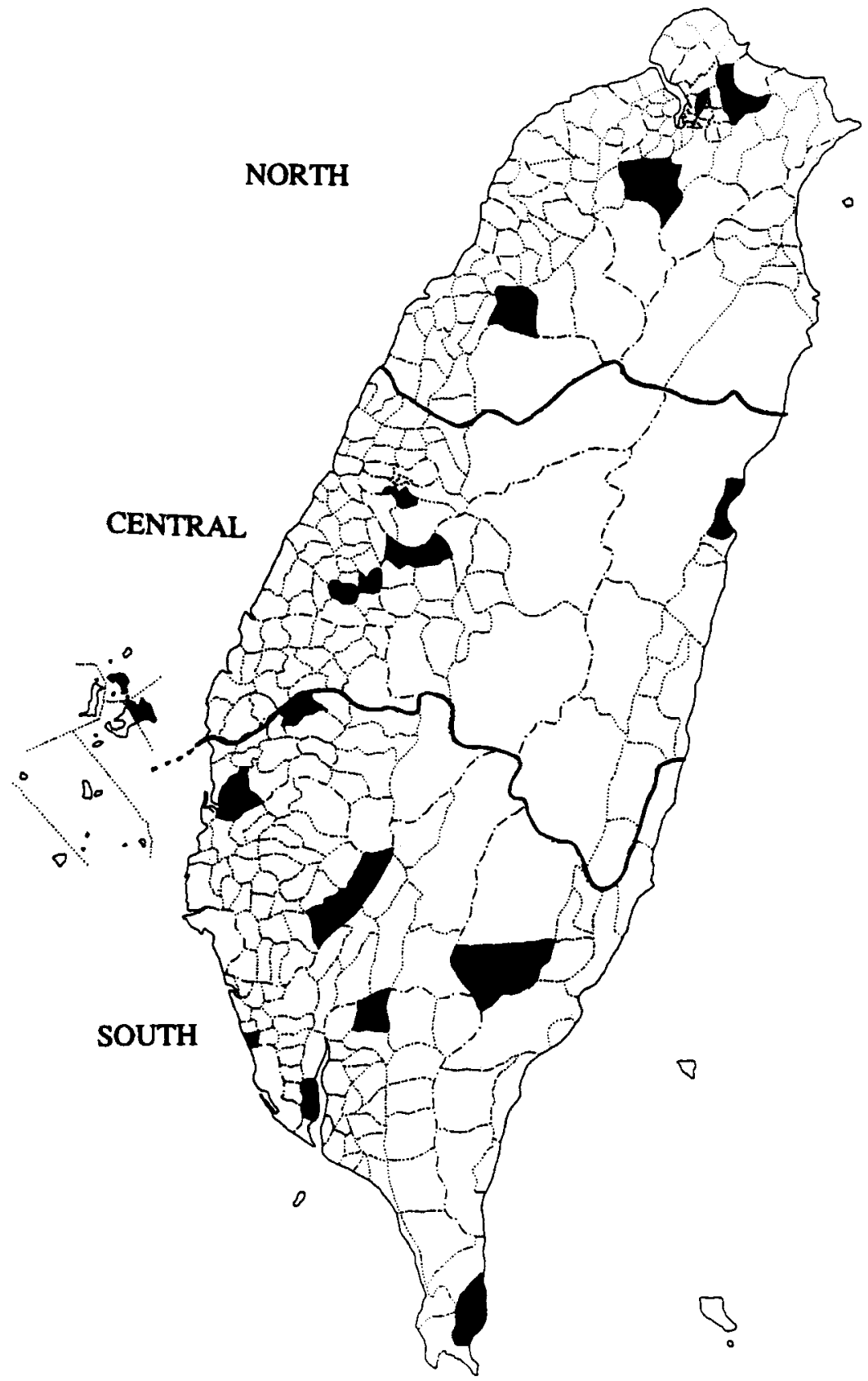

Fig. 1. The map of Taiwan showing 20 townships and metropolitan precincts (shaded) randomly selected in this study.

With the specific aim of examining the secular trend and geographical variation in prevalence of HAV infection and $\mathrm{HBsAg}$ carriage, 875 adolescents selected randomly from 20 townships and precincts were studied.

\section{SUBJECTS AND METHODS}

In order to obtain a representative sample of junior high school children in Taiwan, stratified random sampling was used to select 20 townships and precincts as shown in Figure 1. Junior high school children were chosen as study subjects for the following reasons: (1) the prevalence of $\mathrm{HAV}$ infection and HBsAg carriage has been reported in previous studies to reach a peak at age 18 or above. It was considered more appropriate to study the prevalence of age groups before the peak in order to make comparisons between different time periods or geographical areas. (2) The junior high school attendance rate in Taiwan was as high as $95 \%$, while the senior high school attendance rate was less than 75\% [Department of Interior, 1990]. Therefore, we were more likely to recruit representative samples from the junior high schools. (3) Adolescents in junior high 
TABLE I. Prevalence of Anti-HAV by Urbanization Level and Geographical Location

\begin{tabular}{lccc}
\hline Variable & $\begin{array}{c}\text { HAV positive no. } \\
\text { tested no. }\end{array}$ & $\begin{array}{c}\text { Prevalence } \\
(\%)\end{array}$ & $\begin{array}{c}\text { 95\% C.I. }{ }^{\mathrm{a}} \text { of } \\
\text { prevalence (\%) }\end{array}$ \\
\hline Urbanization Level & & & \\
$\quad$ Metropolitan precinct & $10 / 75$ & 13.3 & $5.6-21.0$ \\
$\quad$ Urban township & $28 / 158$ & 17.7 & $11.8-23.7$ \\
Rural township & $186 / 587$ & 31.7 & $27.9-35.5$ \\
Aboriginal township & $52 / 55$ & 94.5 & $88.4-100.5$ \\
Geographical Location & $18 / 170$ & 10.6 & $6.0-15.2$ \\
$\quad$ North & $74 / 308$ & 24.0 & $19.3-28.8$ \\
Central & $184 / 397$ & 46.3 & $41.4-51.3$ \\
$\quad$ South & $276 / 875$ & 31.5 & $28.5-34.6$ \\
Total & & & \\
\hline
\end{tabular}

${ }^{\mathrm{a}}$ C.I.: Confidence interval.

schools were the latest birth cohorts who had not been immunized against HBV at birth. Thus, there was no bias in their HBsAg carrier rate caused by the vaccination. Eight-hundred and seventy-five junior high school children aged between 13 and 16 years (Mean \pm standard deviation $=14.3 \pm 1.0$ ) were recruited for the study.

Blood samples were collected from the subjects during January to May 1991, using disposable needles and vacuum syringes. Serum samples were centrifuged, separated into aliquots, and stored at $-70^{\circ} \mathrm{C}$ until examined. Antibody to HAV (anti-HAV) and HBsAg in serum were examined by enzyme immunoassay using commercial reagents (Abbott Laboratories, North Chicago, IL) according to the manufacturer's manuals.

The prevalence and the 95\% confidence intervals were estimated for anti-HAV and HBsAg carriage, respectively. The differences in the prevalence of HAV infection or HBsAg carriage in various strata of independent variables including urbanization level, geographical location, or number of physicians per 1,000 population were tested for statistical significance by the chi-square test. Multiple logistic regression analysis was used to estimate the adjusted odds ratios.

To assess the secular trends in HAV prevalence and HBsAg carrier rate, results of previous studies carried out on subjects of the same age range in the same geographical location, i.e., Taipei City and County [Wu et al., 1980a,b, 1982; Hwang et al., 1983; Sung et al., 1980; Hsu et al., 1985] were compared with the results from the present study.

\section{RESULTS \\ HAV Infection Prevalence}

The overall prevalence of anti-HAV was $31.5 \%$, with a range of 6.8 to $94.5 \%$ in the 20 study townships and precincts. The associations between anti-HAV prevalence and urbanization level and geographical location are shown in Table I. The prevalence was as high as $94.5 \%$ in aboriginal townships, $31.7 \%$ in rural townships, $17.7 \%$ in urban townships, and as low as $13.3 \%$ in metropolitan precincts. The prevalence increased from $10.6 \%$ in northern Taiwan, to $24.0 \%$ in central Taiwan, to $46.3 \%$ in southern Taiwan. The results of multiple logistic regression analysis of HAV prevalence are
TABLE II. Multiple Logistic Regression Analysis of HAV Prevalence

\begin{tabular}{lll}
\hline Variable & \multicolumn{1}{c}{ Comparison } & \multicolumn{1}{c}{$\mathrm{OR}^{\mathrm{a}}$} \\
\hline Geographical Location & North & 1.00 \\
& Central & $2.16^{* *}$ \\
& South & $3.49^{* * *}$ \\
Urbanizational Level & Metropolitan precinct & 1.00 \\
& Urban township & 1.20 \\
& Rural township & 1.20 \\
& Aboriginal township & $2.97^{*}$ \\
\hline
\end{tabular}

"OR: Odds ratio.

$* 0.05<P<0.1$.

$* * P<0.01<P<0.05$

称冰 $P<0.01$.

shown in Table II. The urbanization level-adjusted prevalence odds ratios (ORs) were 3.5 and 2.2 , respectively, in southern and central Taiwan, when compared with northern Taiwan as the reference $(\mathrm{OR}=1.0)$. After adjusting for geographical location, the prevalence ORs were $3.0,1.2$, and 1.2 , respectively, for aboriginal townships, urban townships, and rural townships compared with metropolitan precincts as reference.

\section{HBsAg Carrier Rate}

The overall HBsAg carrier rate was $18.9 \%$, with a range of 8.0 to $41.8 \%$ in the 20 study townships and precincts. The association between HBsAg carriage and urbanization level and geographical location are shown in Table III. The rate was as high as $41.8 \%$ in aboriginal townships, $19.1 \%$ in rural townships, $12.0 \%$ in urban townships, and as low as $14.7 \%$ in metropolitan precincts. There was no difference in HBsAg carriage rate in different geographical locations; the rates were $18.8 \%, 18.5 \%$, and $19.1 \%$, respectively, in northern, central, and southern Taiwan. Results of multiple logistic regression analysis of $\mathrm{HBsAg}$ carrier rate are shown in Table IV. The multivariate-adjusted OR of HBsAg carrier status was 3.2 for aboriginal school children as compared with those in nonaboriginal townships as the reference. No significant association was observed for geographical location with an OR of 1.1 and 0.7 for central and southern Taiwan, respectively, as compared with northern Taiwan as reference. There was a significant inverse relationship between the HB$\mathrm{sAg}$ carrier rate and number of physicians per 1,000 
TABLE III. Prevalence of HBsAg by Urbanization Level and Geographical Location

\begin{tabular}{lccr} 
Variable & $\begin{array}{c}\text { HBsAg positive no. } \\
\text { tested no. }\end{array}$ & $\begin{array}{c}\text { Prevalence } \\
(\%)\end{array}$ & $\begin{array}{r}\text { 95\% C.I.a of } \\
\text { prevalence (\%) }\end{array}$ \\
\hline Urbanization Level & & & \\
$\quad$ Metropolitan precinct & $11 / 75$ & 14.7 & $6.7-22.7$ \\
$\quad$ Urban township & $19 / 158$ & 12.0 & $7.0-17.1$ \\
$\quad$ Rural township & $112 / 587$ & 19.1 & $15.9-22.3$ \\
$\quad$ Aboriginal township & $23 / 55$ & 41.8 & $28.8-54.9$ \\
Geographical Location & & & \\
$\quad$ North & $32 / 170$ & 18.8 & $12.9-24.7$ \\
Central & $57 / 308$ & 18.5 & $14.2-22.8$ \\
$\quad$ South & $76 / 397$ & 19.1 & $15.3-23.0$ \\
Total & $165 / 875$ & 18.9 & $16.3-21.4$ \\
\hline
\end{tabular}

C.I.: Confidence interval.

TABLE IV. Multiple Logistic Regression Analysis of HBsAg Prevalence

\begin{tabular}{|c|c|c|}
\hline Variable & Comparison & $\mathrm{OR}^{\mathrm{a}}$ \\
\hline \multirow[t]{4}{*}{$\begin{array}{l}\text { Number of physicians } \\
\text { per } 1,000 \text { population }\end{array}$} & $\begin{array}{l}\geqslant 3.0 \text { physicians } / 1,000 \\
\text { pop. }\end{array}$ & 1.00 \\
\hline & $2.0^{1}$ & 0.8 \\
\hline & 1.0 & $1.6^{*}$ \\
\hline & $\begin{array}{l}<1.0 \text { physician } / 1,000 \\
\text { pop. }\end{array}$ & $2.0^{* * *}$ \\
\hline \multirow[t]{3}{*}{ Geographical location } & North & 1.00 \\
\hline & Central & 1.1 \\
\hline & South & $0.66^{*}$ \\
\hline \multirow[t]{2}{*}{ Urbanization level } & Nonaboriginal township & 1.00 \\
\hline & Aboriginal township & $3.2^{* * * * * *}$ \\
\hline
\end{tabular}

"OR: Odds ratio.

$0.05<P<0.1$

**: $0.01<P<0.05$

**: $P<0.01$

TABLE V. Comparison of HAV Prevalence Among Junior High School Children in Taipei City and County by Calendar Years

\begin{tabular}{|c|c|c|c|}
\hline \multirow[b]{2}{*}{ Authors |year] } & \multicolumn{2}{|c|}{ Blood collection } & \multirow{2}{*}{$\begin{array}{c}\text { HAV } \\
\text { Prevalence } \\
(\%)\end{array}$} \\
\hline & Year & Area & \\
\hline Wu et al. |1980| & $\mathrm{NA}^{\mathrm{a}}$ & Taipei County & 91.5 \\
\hline Hwang et al. |1983| & $1975 \ldots 6$ & Taipei City & 89.2 \\
\hline Sung et al. $|1980|$ & $1976-8$ & Taipei City & 78.9 \\
\hline Wu et al. |1982] & 1979 & Taipei City & 61.8 \\
\hline Hsu et al. |1985| & 1984 & Taipei City & 13.6 \\
\hline This study [1993] & 1991 & $\begin{array}{l}\text { Taipei City } \\
\text { and County }\end{array}$ & 10.1 \\
\hline
\end{tabular}

"NA: not available.

population; ORs were $0.8,1.6$ and 2.0 for areas where the numbers of physicians per 1,000 population were 2 , 1 and less than 1 , respectively, when compared with the areas where there were more than 3 physicians per 1,000 population.

\section{Secular Trend in Taipei City and County}

The secular trend of HAV prevalence among adolescents in Taipei City and County is shown in Table V. The HAV prevalence in Taipei has declined significantly since the 1970 s. The prevalence decreased significantly from 91.5 to $61.8 \%$ during the $1970 \mathrm{~s}$, and
TABLE VI. Comparison of HBsAg Carrier Rate Among Junior High School Children in Taipei City and County by Calendar Years

\begin{tabular}{|c|c|c|c|}
\hline \multirow[b]{2}{*}{ Authors [year] } & \multicolumn{2}{|c|}{ Blood collection } & \multirow{2}{*}{$\begin{array}{c}\mathrm{HBsAg} \\
\text { carrier rate } \\
(\%)\end{array}$} \\
\hline & Year & Area & \\
\hline Wu et al. [1980] & $\mathrm{NA}^{\mathrm{a}}$ & Taipei County & 25.5 \\
\hline Sung et al. [1984] & $\mathrm{NA}$ & Taipei City & 20.9 \\
\hline Hsu et al. [1986] & 1984 & Taipei City & 11.7 \\
\hline This study [1993] & 1991 & Taipei City & 11.4 \\
\hline
\end{tabular}

"NA: not available.

dropped further down to $13.6 \%$ in 1984 . However, the HAV prevalence has declined by only $2.5 \%$ during the last seven years. The secular trend of HBsAg carrier rate is shown in Table VI; the rate among adolescents in Taipei City and County declined significantly from $25.5 \%$ in the late 1970 s to $13.9 \%$ in this study.

\section{DISCUSSION}

HAV is transmitted mainly by the fecal-oral route [Dienstag et al., 1978; Benenson, 1990]. Accordingly, the prevalence of HAV infection is determined by conditions of environmental hygiene including sewage disposal, water supply, and food hygiene IChen et al., 1990; Hsu et al., 1985; Hwang et al., 1983]. Before the economic boom which started in the mid-1970s, sewage disposal and the water supply system were not satisfactory in Taiwan. Furthermore, human excreta and sewage sludge were used for fertilizing both dry and muddy crop fields. Surface and well water were both used as drinking water before the availability of water supply networks. Consequently, HAV infection in Taiwan has been as high as more than $90 \%$ among adults [Sung et al., 1980; Wu et al., 1980b, 1982], with peak prevalence at the age of 20 years [Sung et al., 1980; Wu et al., $1980 \mathrm{a}]$.

In the present study, the increase in HAV prevalence from the subtropical north to the tropical south of Taiwan may be due to increase in temperature and other conditions which are more suitable for transmission of HAV in the environment. The striking difference in HAV infection prevalence in areas of different urbanization levels may be due to their conditions of sewage 
disposal and water supply. The extraordinarily high prevalence in aboriginal areas may be due to the poor environmental hygiene and drinking water sanitation. Most residents in aboriginal areas obtain drinking water from rivers or lakes which are frequently contaminated with human excreta.

The significant decline in HAV prevalence in Taipei City in recent years may be due to the increased availability of a clean water supply, better management of food hygiene, reduced use of "night soil" as fertilizer, and an improved sewage disposal system. The coverage of piped water supply in Taipei City increased from $92 \%$ in 1976 to $99 \%$ in 1990 . However, it is noteworthy that the prevalence of $\mathrm{HAV}$ infection has remained at around 10\% in Taipei City since 1985. An investigation of possible transmission routes is required for further control of HAV infection in Taipei and Taiwan generally. Furthermore, as the level of HAV infection becomes progressively lower in Taiwan, there will be a rapid increase in the density of susceptible people in the general population in Taiwan. In order to prevent future outbreaks of $\mathrm{HAV}$, vaccination against $\mathrm{HAV}$ is necessary.

HBV is transmitted in Taiwan by both perinatal and horizontal routes. In the 1970 s, the HBV infection rate was as high as $90 \%$, with an HBsAg carrier rate of $20 \%$ among adults [Beasley, 1975; Wu et al., 1980]. The age-specific $\mathrm{HBV}$ infection prevalence levelled after 20 years old, and the HBsAg carried rate peaked even earlier at preschool ages [Sung et al., 1984]. In other words, most HBsAg carriers in Taiwan were infected during early childhood [Sung et al., 1984; Hsu et al., 1986; Beasley, 1975], and infection occurred either perinatally or horizontally during the preschool years. In the present study, the secular trend of HBsAg carrier rate in Taipei City and County showed a significant decline from $25 \%$ in 1980 to $11 \%$ in 1991 . Neither promiscuity nor parenteral drug abuse were important in infection with $\mathrm{HBV}$ in carrier children. In addition, the $\mathrm{HBs} A g$ carrier rate was related inversely to the number of qualified physicians per 1,000 population. However, as the number of physicians may be correlated with the socioeconomic status and the degree of development of a given community, the inverse relationship between number of physicians and HBsAg prevalence requires further investigation.

Aboriginal junior high school children were found to have a higher HBsAg carriage rate than those in other areas. This finding is consistent with those reported in other studies [Beasley, 1975; Chen et al., 1990; Chung et al., 1987]. However, aborigines in Orchid Island, a small island located to the southeast of Taiwan, have a very low HBsAg carrier rate [You et al., 1990]. It was concluded that the ethnic background itself was not associated with the high $\mathrm{HBsAg}$ carrier rate among aborigines in Taiwan Island. In this study, the high HBsAg carrier rate among aboriginal school children remained significant after adjustment for the number of physicians per 1,000 population and geographical locations. In addition to the high HBsAg prevalence in aboriginal areas [Chung et al., 1987], some other factors may account for the increased HBsAg carrier rate among aborigines. From the public health point of view, mass HBV vaccination is of particular importance in aboriginal areas.

\section{ACKNOWLEDGMENTS}

This study was supported by a grant from the Department of Health, Executive Yuan, Republic of China. The authors also thank Dr. C. Fletcher for helpful suggestions.

\section{REFERENCES}

Benenson AS (1990): "Control of Communicable Diseases in Man." Washington DC: American Public Health Association, pp 197-200.

Beasley PR (1975): The epidemiology of hepatitis B infection in Taiwan. Journal of Formosan Medical Association 74:681-682.

Chen CJ, You CY, You SL, Lu CF, Hsu ST (1990): Seroepidemiology of hepatitis A, B and D viruses among children in Taiwan. In Sung JL, Chen DS (eds): "Viral Hepatitis and Hepatocellular Carcinoma." Hong Kong: Excerpta Medica Asia Ltd., pp 9-15.

Chung DC, Ko YC, Chen CJ, Wu CC, Wang ZH (1987): Epidemiology study on hepatitis B virus infection among five ethnic group in Pingtung county, Taiwan. Joumal of Formosan Medical Association 86:497-504.

Chung DC, Ko YC, Chen CJ, Chen ER, Wu CC, Wu PS (1989): Seroepidemiology of hepatitis $B$ virus, hepatitis $D$ virus, and human immunodeficiency virus infections among parenteral drug abusers in southern Taiwan. Journal of Medical Virology 28:215-218.

Department of Health (1990): "Health Statistics: I. Administrative Statistics." Taipei: Department of Health, Executive Yuan.

Department of Interior (1990): "1989 Taiwan-Fukien Demographic Fact Book." Taipei: Department of Interior, Executive Yuan.

Dienstag JL, Szmuness W, Stevens CE, Purcell RH (1978): Hepatitis A virus infection from seroepidemiologic studies. Journal of Infection Disease 137:328-340.

Hsu HM (1990): Epidemiology of Hepatitis B Virus and Implementation and Evaluation of Hepatitis B Vaccination in Taiwan. "Department of Health, pp 95-105.

Hsu HY, Chang MH, Chen DS, Lee CY, Sung JL (1985): Changing seroepidemiology of hepatitis A virus infection in Taiwan. Journal of Medical Virology 17:297-301.

Hsu HY, Chang HM, Chen DS, Lee CY, Sung JL (1986): Baseline seroepidemiology of hepatitis $B$ virus infection in children in Taipei, 1984: A study just before mass hepatitis B vaccination program in Taiwan. Journal of Medical Virology 18:301-307.

Hwang LY, Beasley RP, Yang CS, Hsu LC, Chen KP (1983): Incidence of hepatitis A virus infection in children in Taipei, Taiwan. Intervirology 20:149-154.

Stevens CE, Beasley RP, Tsui J, Lee WC (1975): Vertical transmission of hepatitis B antigen in Taiwan. New England Journal of Medicine 292:771-774.

Sung JL, Chen DS, Yu JU, Wang TH, Lay MY, Wang CY, Lai MS (1980): Hepatitis A virus infection in Taiwan a hospital-based study. Tropical and Geographical Medicine 32:324-328.

Sung JL, Chen DS, Lai MY, Yu JY, Wang TH, Wang CY, Lee CY, Chen SH, Ko TM (1984): Epidemiology study on hepatitis B virus infection in Taiwan. Chinese Journal of Gastroenterology 1:1-9.

Wu JS, Chen CH, Chiang YH, Lee YC, Lee MH, Ko YC (1980a): Hepatitis A virus infection in Taiwan. Journal of Formosan Medical Association 79:694-699.

Wu JS, Chen $\mathrm{CH}$, Chiang YH, Lee YC, Lee MH, Ko YC, Hu HT (1980b): Hepatitis B virus infection in Taiwan with reference to anti-HBc versua $\mathrm{HBsAg}$ and anti-HBs, Journal of Formosan Medical Association 79:760-767.

Wu TC, Hsieh KS, Wang HC, Wong YL, Shiao IS, Kwan SH, Yeh SH (1982): Seroepidemiology of hepatitis A infection in children in Taiwan. Journal of Formosan Medical Association 81:1012-1016.

You SL, Lu CF, Hsu ST, Liu WT, Chen CJ (1990): Seroepidemiology of hepatitis $A$ and $B$ viruses among aboriginal children in Orehid Island. In Sung JL, Chen DS (eds): "Viral Hepatitis and Hepatocellular Carcinoma." Hong Kong: Excerpta Medica Asia Ltd., pp 1621. 